\title{
WORLD CLASS MANUFACTURING (WCM) MODEL AND OPERATIONAL PERFORMANCE INDICATORS: COMPARISON BETWEEN WCM FIRMS
}

\author{
Emre Bilgin SARI*
}

\begin{abstract}
World Class Manufacturing is an application system that combines best practices which are compatible with each other so that businesses can continue their activities systematically. WCM model has ten operational pillars. In this study, the operational pillars of the WCM model and the performance indicators in which the applications of these pillars are followed are elaborated. The study was designed to monitor operational performance in the WCM model with the help of Key Performance Indicators (KPI) and investigate the effects of operational pillars and performance indicators on total WCM performance. In the research part of the study, two different WCM operator firms are compared and their KPIs are shared.
\end{abstract}

Keywords: World Class Manufacturing, Operational Performance, Performance Indicators, KPI.

\section{DÜNYA KLASINDA ÜRETIM MODELI VE OPERASYONEL PERFORMANS GÖSTERGELERI: WCM FIRMALARI ARASINDAKI KARŞILAŞTIRMA}

\section{Öz}

Dünya Klasında Üretim, işletmelerin faaliyetlerini sistematik olarak sürdürebilmeleri amacıyla en iyi uygulamaları bir araya getiren sistemi tanımlamaktadır. WCM modelinde on adet sütun vardır. Bu çalışmada, WCM modelinin operasyonel sütunlar ve bu sütunların uygulamalarının takip edildiği performans göstergeleri detaylandırımıştır. Çalışma, anahtar performans göstergelerinin yardımıyla WCM modelindeki operasyonel performansı izlemek ve operasyonel sütunların toplam WCM performansı üzerindeki etkilerini araştırmak üzere tasarlanmıştır. Çalışmanın araştırma bölümünde, WCM uygulayıcısı iki farklı firma karşılaştırılmış ve anahtar performans göstergeleri sonuçları kıyaslanmıştır.

Anahtar Sözcükler: Dünya Klasında Üretim, Operasyonel Performans, Performans Göstergeleri, KPI.

\footnotetext{
* Dokuz Eylül University, Faculty of Economics and Administrative Sciences, Department of Business Administration, İzmir, E-mail: emre.bilgin@deu.edu.tr
} 


\section{World Class Manufacturing (WCM) Model and Operational Performance Indicators: Comparison Between WCM Firms}

\section{INTRODUCTION}

World Class Manufacturing (WCM) was first proposed by Hayes and Wheelwright in 1984 to bring together the best practices for the development of manufacturing enterprises after the industrial revolution. In the late 1980s, Richard J. Schonberger (1986) showed that WCM is a common language for concepts such as just-in-time, total productive maintenance, total quality management, lean manufacturing and employee involvement in order to explain the different types of techniques used in different places at different times in modern production systems. WCM was developed and used as a model in 2006 to overcome the crisis in the Fiat Chrsyler Automobile (FCA) Group. WCM model is based on zero waste, zero defects, zero inventories and zero failure.

The WCM model designed a systematic structure that requires the applications be used in conjunction with best practices in their operations, and these applications must be compatible and synchronized simultaneously. To better illustrate this structure, the WCM model is followed by ten managerial and ten operational pillars. The pillars of the WCM model are the result of a very comprehensive work requiring major expertise. This has been the way in which researchers are treated separately by considering the depths of the applications and by analyzing the model in terms of depth and by dividing them into world-class logistics, world-class quality and world-class maintenance. However, researches that deal with the effects of these issues without division and their coapplication are rarely found to have labor constraints such as time and cost for research.

Literature review on operational performance has some remarkable headings appear in the foreground. Venkatraman and Ramanujam, in their work in 1986, emphasized the measurement of business performance in strategy research and compared approaches. This issue emphasizes the importance of measuring business performance. Then, Ferdows and Meyer (1990) have tried to make permanent improvements in production performance and have focused on performance indicators. So performance indicators have become important. Vincent and Hu (2010) utilized fuzzy multi-criteria decision making while Quagini and Tonchia (2010) linked balanced scorecard in the modeling of the effect in performance measurement. Following all these studies, performance evaluation for World Class Manufacturing is encountered by Chiarini and Vagnoni (2015) evaluating Toyota's Just-in-Time Production Model and Fiat's WCM model 


\section{Emre Bilgin SARI}

with strategic management, management accounting, operation management and performance measurement dimensions. Although all these studies reviewed in the literature have contributed to the literature, they show that lack of an integrative study for WCM model about operational performance of pillars.

The WCM model takes operational pillar as a whole and achieves the conclusion that the integral parts will arrive at the same time for the purpose of the model if they rise simultaneously. This study examines the performance indicators required to monitor operational performance in the WCM model. In the first part of the work, the WCM model and the operational pillars of this model are explained and then, performance indicators used in the success of operational pillars are elaborated. In the second part, performance indicators used in the success of operational pillars are included. In the application part of the study, two different enterprises that implement the WCM model are examined. The explored businesses continue to implement the WCM model at different stages. For this reason, it is aimed to compare the results of the performance indicators of the enterprises and to show the change between the results at different stages.

\section{WORLD CLASS MANUFACTURING (WCM) MODEL}

The concept of WCM it is the extension of many principles which were first appeared in Japan in the 1950s and 1960s and successfully applied in many other countries (De Felice, Petrillo and Monfreda, 2013). Yamashina (1995) constructed the WCM structure on ten operational and ten managerial pillars in order to customize it according to needs. The WCM definition proposed by Yamashina is a business model that combines applied research, production engineering, the ability to improve, and the use of detailed workshop knowledge to combine the components of production superiority (Palucha, 2012). Accordingly, the WCM model predicts a rise in operational, managerial pillars that integrate business functions into a systematic way. Simultaneous ascending of the pillars is an essential prerequisite for integrated success. Achievement levels of operational areas are indirectly affected by levels of achievement of management areas. The pillar structure represents the "World Class Manufacturing House" and all the pillars need to be developed in parallel to achieve the standard of excellence. Each pillar focuses on a specific area of the production system using appropriate tools to achieve global excellence (Felice et al., 2013). Figure 1 shows World Class Manufacturing Model. 


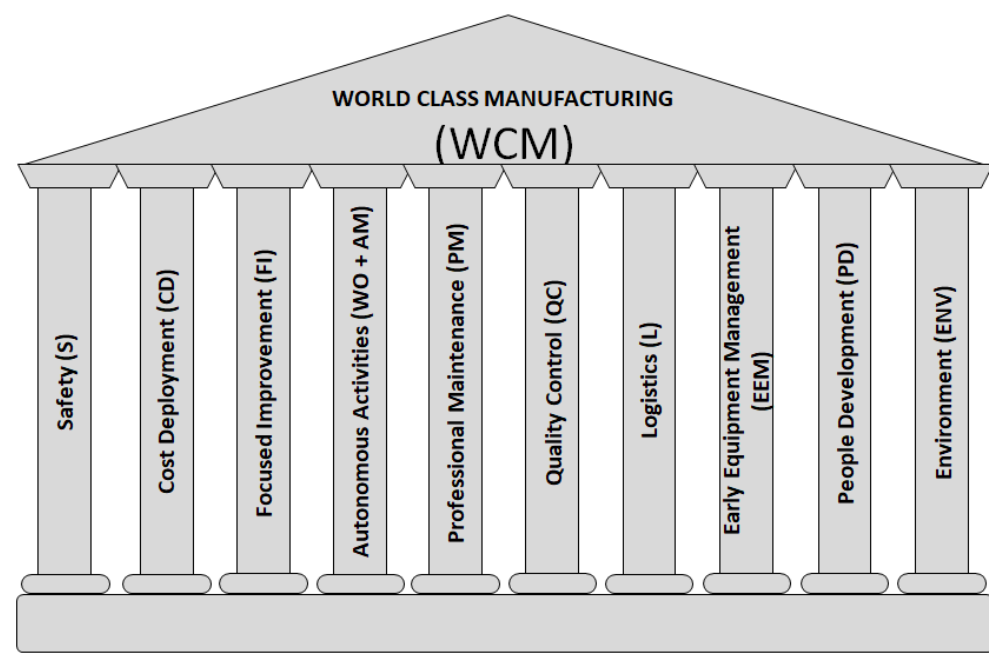

Source: Palucha, 2012.

\section{Figure 1: World Class Manufacturing Model}

WCM is a model that combines the best practices used in manufacturing research. The practices of this model, which the companies bring together in harmony with each other while operating, are supported by the Fiat Chrysler Automobile (FCA) and the spread to the automotive industry, subcontracting and supplier companies is continuing rapidly (Stanek, Czech and Barcik, 2011).

The WCM model is based on a systematic structure that requires the best practices to be used together in the operations of the enterprises, as well as those applications that need to be maintained in a harmonious and multidimensional structure, moving from the point of view of coordinating with each other, as well as following the basic issues of competition, such as cost, quality, speed and flexibility. To better illustrate this structure, the WCM model is shown as a roof rising on pillars. The ten pillars in the model are essential centers of activity for carrying the roof.

Building blocks that are indispensable for the WCM model are starting with the pillar health and safety. In the world class manufacturing model, the "Safety" (S) pillar is based on constantly improving the working environment, removing the conditions and behaviors that could lead to accidents or injuries, and preventing occupational diseases (Gajdzik, 2013).

Awareness of costs is the second strength of the WCM model. The "Cost Deployment" (CD) pillar in the world class manufacturing model is a scientific and systematic cost reduction method carried out by production 


\section{Emre Bilgin SARI}

and accounting staff. The relationship between the studies based on the analysis of loss and CD-Pillar determine cost factors provides for the uncovering and reduction of costs and other unknown wastes and losses in the process (Djordjevic, Milovanovic and Djordjevic, 2010).

The improvement pillar is responsible for helping correct any missing, flawed, or faulty cases encountered in all other pillars within the model. The "Focused Improvement" (FI) pillar in the world-class manufacturing model is based on an approach that constantly incorporates problem-solving methods that must be applied to optimize the work environment and solve or evaluate all problems and opportunities in the most optimal way (Morgan, 1997).

The autonomous operations aim at the operation of the WCM model for operator machine dependence. The "Autonomous Activities" (AA) pillar studies in the world class manufacturing model are conducted in two phases (Autonomous Maintenance / AM and Workplace Organization / WO) (Murino, Naviglio, Romano, Guerra, Revetria, Mosca and Cassettari, 2012). This pillar, which aims to provide a working environment where the employees keep their machine environment regularly working by daily lubrication, cleaning and maintenance which the machines own, owns the operators as the members of the house and encourages everyone to be responsible for their business areas.

The maintenance pillar is responsible for all kinds of electronic and mechanical maintenance due to industrial requirements. In the world class manufacturing model, the "Professional Maintenance" (PM) pillar is working on reducing machine failures and increasing equipment effectiveness (Börjesson, 2011).

The quality pillar is responsible for carrying out quality studies. In the world class manufacturing model, the "Quality Control" (QC) pillar focuses on determining process conditions, maintaining predetermined conditions and ensuring production compliance to prevent nonconformities (Szewieczek, Roszak and Helizanowicz, 2008).

The logistics pillar covers a wide range of areas from raw material and material supply for production enterprises to in-plant warehouse layouts, production area movements, semi-finished stocks, transportation of finished products to customers, In the world class manufacturing model, "Logistics" (LOG) pillar is working on the creation of customer satisfaction by keeping the material handling at minimum level, making production compatible with market demands, correct product, right time and right number of systems (Dudek, 2013). 


\section{World Class Manufacturing (WCM) Model and Operational Performance Indicators: Comparison Between WCM Firms}

Early equipment management pillar is responsible for equipment management to make the necessary innovation. The "Early Equipment Management (EEM)" pillar in the world-class manufacturing model continues to improve equipment. EEM focuses on improving the product design process (Mishra, Anand and Kodali, 2006).

The pillar of employee development is carried out with human resource management support in the WCM model. In the world-class manufacturing model, the "People Development / PD" pillar is based on humanitarian concerns, sincere interests and valorization. Parallel progress has been achieved by overlapping the targets of employees in the direction of in-house strategies and policies (Szwejczewski and Jones, 2012).

Finally, the environmental pillar is also responsible for environmental issues and energy management within the enterprise. The "Environment" (ENV) pillar in the world class manufacturing model is concerned with the establishment of the environmental management system and the adoption of the basic principles.

The world-class manufacturing model is applicable to all institutions and organizations that are active, as well as being the starting-point industry enterprises. World class health, world class education, world class tourism, world class communication, world class services such as open to different areas and will be applied to every innovative and developmental support will lead to a philosophy. The contributions that it provides are the result of a quest to achieve consistently the best that the building stones on which the model is based basically can adapt to different businesses. Every business is supported by the fact that it has a different and unique characteristics as well as being world class to try to catch perfection in its processes and to accept itself as a philosophy of renewal.

\section{OPERATIONAL PERFORMANCE INDICATORS IN THE WORLD CLASS MANUFACTURING MODEL}

In the World Class Manufacturing (WCM) structure, the existing operational pillars for the systematic execution of business processes in the field of work are carried on with the application tools they have in their own structures. The application tools are the projection of the steps followed in the pillars with the Key Activity Indicators (KAI) in the work area and the progress of the pillar activities are monitored step by step with Key Performance Indicators (KPI).

The KAI of the operational pillars in the WCM structure are intended to follow pillar operations. As the WCM is based on a philosophy that 


\section{Emre Bilgin SARI}

requires continuity, the KAI are operational according to the development and change of the model. The KAI used in the seven-step approach due to the progress of the reactive, preventive and proactive phases of the WCM model are determined in accordance with the needs of the operational pillars. While the KAI are handled by the pillar teams to ensure that the ten operational pillars that make up the operational structure of the WCM are being simultaneously tracked, the activities of the pillars affecting each other are also being coordinated with KPI. The links between the KPI and the KAI used in the pillars are established, and the points to be influenced are determined to contribute to the progress of the remaining indicators. The importance of these KPI should be assessed in such a way that each pillar is treated separately, and includes the other pillars where they affect the results. Figure 2 is prepared to show the position of the KPIs in the WCM model.

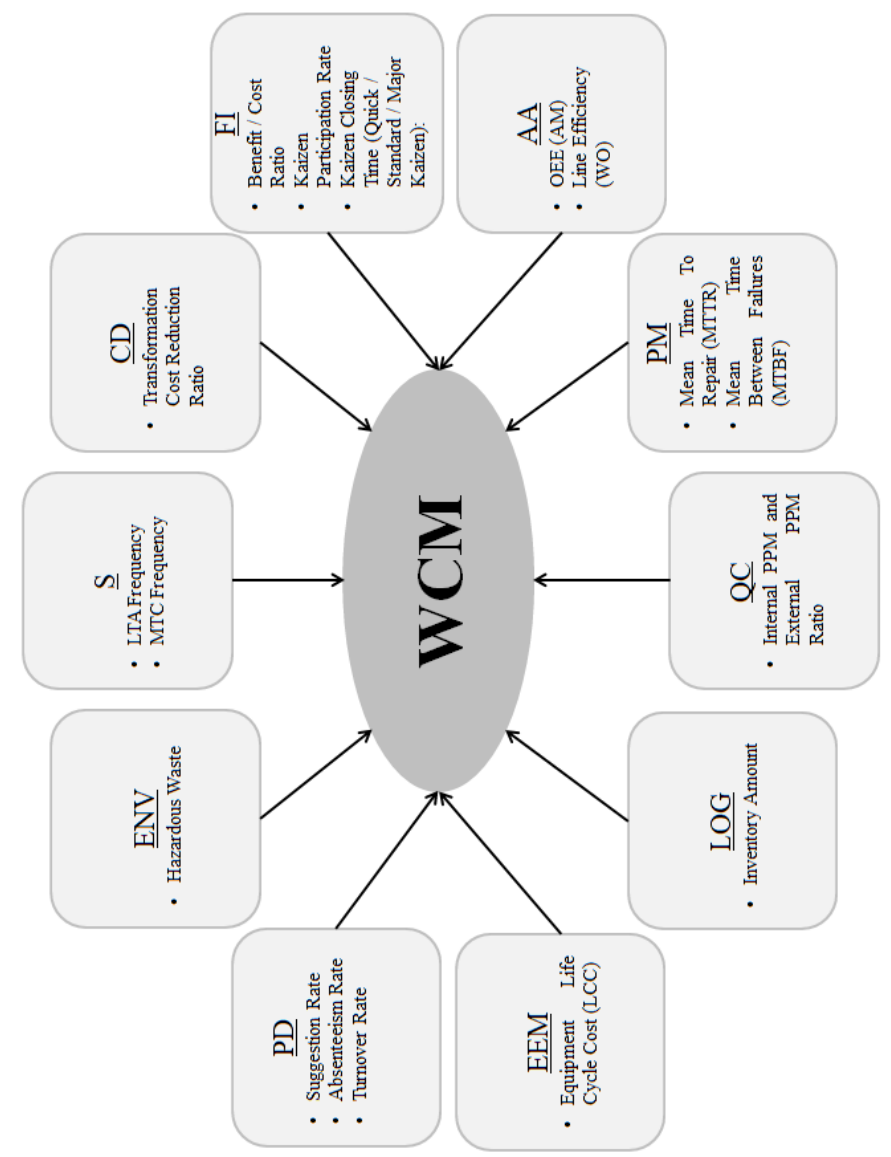

Figure 2: KPIs of WCM Model 


\section{World Class Manufacturing (WCM) Model and Operational Performance Indicators: Comparison Between WCM Firms}

\section{Safety (S) Pillar Performance Indicators}

Safety (S) Pillar is the basic unit where all activities related to worker health and work safety are conducted in the WCM structure. The S-Pillar team continues to work with a safer workplace and zero-work accident target. It aims to create an environment in which there is no business accidents for a world-class workplace, and the activities of the S-Pillar will continue as long as they work in the workplace. The performance indicators for tracking these activities can be explained as follows:

- Lost Time Accident (LTA), First Aid - Medication and Close Accident (FA - MCA) Frequencies: The number and frequency of accidents in the workplace is monitored by the $S$ pillar team. Accidents are divided into lost days, first aid and close accidents. When a lost day accident occurs, the employee does not come to work as a report. The first aid accident refers to the type of accident in which the employee after the work accident does not separate from the overworked workday during the first aid or emergency operation. Close accidents are events that do not cause any injuries, but are potentially disadvantaged (Andersen and Fagerhaug, 2006). The calculations of these KPI's are explained in equation 1 and equation 2. Number of accidents and 100.000 is multiplied and result is divided to working time in the equation. So the accident frequency is calculated.

LTA Frequency $=\frac{(\text { Number of LTA } \times 100.000)}{\text { Working Hours }}$

$F A-M C A$ Frequency $=\frac{(\text { Number of FA-MCA } \times 100.000)}{\text { Working Hours }}$

\section{Cost Deployment (CD) Pillar Performance Indicators}

The Cost Deployment (CD) pillar, within the WCM model, manages the work that is done to uncover losses and wastes in the workplace, determines the costs of the losses introduced, and prepares the groundwork for the improvements that must be made to avoid these losses. The performance indicator for CD-Pillar is about transformation cost and the calculation of reduction ratio of this cost is explained in equation 3. 


\section{Emre Bilgin SARI}

- $\quad$ Transformation Cost Reduction Ratio: The cost of transformation is composed of costs directly linked to production units, such as direct labor, as well as fixed and variable overall production costs arising from the conversion of raw materials into products. It can also be called the cost of transformation. And ratio for reduction in this cost is about the contribution to the improvement. FI-Pillar can manage the improvement activities.

Transformation Cost Reduction Ratio $=\frac{\text { improvement }}{\text { transformation }}$

\section{Focused Improvement (FI) Pillar Performance Indicators}

The Focused Improvement (FI) pillar relates to quick, standard, and major kaizen activities, participation in kaizen, kaizen completion times and cost of kaizen are performance indicators (Sarı, 2016). Performance indicators of FI-Pillar can explain as:

- $\quad$ Average Benefit / Cost Ratio: The total gained profit is based on the cost of the improvements made.

- Kaizen Participation Rate: Kaizen work is monitored by the FIPillar, but it is organized to cover all employees' participation. The participation rate of white-collar workers and blue-collar employees is therefore regarded as a performance indicator for FIPillar activities.

- Kaizen Closing Time (Quick / Standard / Major Kaizen): Kaizen studies are spreading differently in terms of the solution level of the problem they deal with. The FI-Pillar follows the improvement activities carried out in the workplace, and monitors the completion times of these improvement activities as performance indicators.

\section{Autonomous Activities (AA) Pillar Performance Indicators}

The Autonomous Activities (AA) pillar is analyzed under two headings as performance indicators, autonomous maintenance and workplace organization.

\section{Autonomous Maintenance (AM) Pillar Performance Indicators}

The Autonomous Maintenance (AM) pillar contains applications for machinery and equipment, maintenance by operators. For this, operators 


\section{World Class Manufacturing (WCM) Model and Operational Performance Indicators: Comparison Between WCM Firms}

are required to be held accountable for the equipment provided with training and to provide operator-controlled machine approach.

- Overall Equipment Effectiveness (OEE): The AM-Pillar follows OEE with the application tools used during the discovery of losses in the work area. It is a measurement technique that shows how the OEE operator benefits from the equipment (Temiz, Atasoy, and Sucu, 2010) OEE calculation is detailed in equation 4.

$O E E=A \times P \times Q$

Availability Rate $(A)=\frac{\text { Operating Time }(h)}{\text { Loading Time }(h)} \times 100$

Operating Time $=$ Loading Time - Down Time

Performance Efficiency $(P)=\frac{\text { Theoretical Cycle Time }(h) \times \text { Actual Output }(\text { Unit })}{\text { Operating Time }(h)}$

Quality Rate $(Q)=\frac{\text { Total Production }- \text { Defect Amount }}{\text { Total Production }(\text { Units })} \times 100$

\section{Workplace Organization (WO) Pillar Performance Indicators}

The Workplace Organization (WO) pillar contains studies to ensure the participation of employees to improve production efficiency and other outputs associated with it, to provide basic conditions and to correct nonvalue-added activities.

- Line Efficiency (Line Balancing): Increasing line efficiency by handling non-value added activities and distributing new duties to business units after the elimination of these activities, improving operation in each business unit and moving business from one station to another and eliminating technical restrictions. The WOPillar follows line efficiency as a performance indicator and calculation is detailed in equation 5 .

Line Efficiency $=\frac{\text { production time }(h)}{\text { working time }(h) \times 100}$

\section{Professional Maintenance (PM) Pillar Performance Indicators}

The Professional Maintenance (PM) pillar governs the identification of maintenance activities and the regulation of activities that can pass to the AM-Pillar, which governs Emergency Work Order (EWO) forms for 


\section{Emre Bilgin SARI}

failures that cannot be handled by operators. In this context, it presents solutions with performance indicators.

- Mean Time To Repair (MTTR): MTTR is the average duration of unplanned downtime caused by unplanned downtime of a work center (Sarı and Doğan, 2015). MTTR calculation is detailed in equation 6 .

$M T T R=\frac{\text { Total Maintenance Time }}{\text { number of repairs }}$

- Mean Time Between Failures (MTBF): Time from MTBF is the occurrence of the lost time caused by the technical problems in the equipment and the failure defined as the stance or function loss. MTBF is defined as the average time between unplanned downtime and failures (Sarı and Doğan, 2015). MTBF calculation is detailed in equation 7.

$M T B F=\frac{\text { operating time }}{\text { number of failures }}$

\section{Quality Control (QC) Pillar Performance Indicators}

The Quality Control (QC) pillar contains the methods used to obtain an overview of the quality problems encountered in the workplace and follows performance indicators in this regard.

- Internal PPM and External PPM Ratio: One of the key performance measures of the QC-Pillar, Parts Per Million (PPM) is an indication of some improvement efforts to determine quality nonconformities, to support the use of pillar applications, and to ensure that operations are more controlled, secure and faster. A PPM value of 1 will be specified if 1 defective part is found in one million pieces purchased. A value of 1 PPM means 1 error in one million (Netsis, 2012). PPM calculation is detailed in equation 8.

$P P M=\left(\frac{\text { Number of incorrect parts }}{\text { Total number of parts }}\right) \times 1.000 .000$

Internal PPM is calculated as division of number of defective pieces to total production amount and result is multiplied one million. The external PPM is calculated as division of number of returned products from customer to total number of shipments and result is multiplied one million. 


\section{World Class Manufacturing (WCM) Model and Operational Performance Indicators: Comparison Between WCM Firms}

\section{Logistics (LOG) Pillar Performance Indicators}

The Logistics (LOG) pillar, which is used for ensuring customer satisfaction by ensuring that material handles are kept at minimum level, associated with market demands of production, correct product, correct time and correct number system, makes applications for reducing stocks by understanding that all of the material handles are lost and providing single piece flow.

- Inventory Amount is KPI of LOG-Pillar. Having high inventory levels increases costs in order to make deliveries faster. Inventory Amount is detailed in equation $9-10-11$. The LOG-Pillar also follows these variables in order not to increase the stock quantity in order to improve the delivery performance indicator (Dudek, 2013).

Line side Inventory $=\frac{\text { Line side Part Amount }}{\text { Daily Average Consumption }}$

Semi - finished Inventory $=\frac{\text { Average Inventory Amount }}{\text { Daily Average Production }}$

Finished Good Inventory $=\frac{\text { Average Inventory Amount }}{\text { Daily Average Production }}$

\section{Early Equipment Management (EEM) Pillar Performance Indicators}

The Early Equipment Management (EEM) pillar helps to learn organizationally and use them in subsequent projects. When an assignment is made with the EEM-Pillar, it takes a lot of time and resources to standardize the process in terms of operation and maintenance approach, to determine the kaizens and to solve most of the problems (Sarl, 2016).

- Equipment Life Cycle Cost (LCC): The EEM-Pillar aims to maximize the efficiency of the equipment. LCC is determined at $95 \%$ design stage. Maintenance and energy costs are also determined at the design stage of the equipment (Chaneski, 2002). The LCC consists of the costs required during the period in which the equipment is used and includes the time period from when the system is defined by its content to when it is removed from the system. LCC can be 


\section{Emre Bilgin SARI}

defined the total amount of initial $\left(\mathrm{C}_{\mathrm{ic}}\right)$, installation $\left(\mathrm{C}_{\mathrm{in}}\right)$, energy $\left(C_{e}\right)$, operation $\left(C_{0}\right)$, maintenance and repair $\left(C_{m}\right)$, stop time $\left(C_{s}\right)$ and decommissioning/disposal $\left(C_{d}\right)$ costs.

$$
L C C=C i c+C i n+C e+C o+C m+C s+C d
$$

\section{People Development (PD) Pillar Performance Indicators}

The People Development (PD) pillar is obliged to manage the development of the competencies of the people and the spreading of the full range of work in certain WCM applications.

- Suggestion Rate: The Suggestion System is a structure that allows employees to think, exchange ideas, make suggestions to improve the operation, and use the initiative (Sarl, 2018). The PD-Pillar ensures that the proposal system is clearly and comprehensibly revealed and follow the rate as an indicator.

Suggestion Rate $=\frac{\text { Number of Suggestion }}{\text { Number of Employees }}$

- Absenteeism Rate: Absenteeism; the employer or the manager should not come to work without informing the employee without any excuse. Employee absenteeism is caused by attitudes towards the worker who are largely inactive when non-employee causes are excluded (illness, familial reasons, transportation disruptions, etc.). The PD-Pillar works to manage this attitude and prevent absenteeism.

$$
\text { Absenteeism }=\frac{\text { Absenteeism Time }}{\text { Total Working Time }}
$$

- Labor Turnover Rate: The labor force is the number of employees who are affected by the turnover, workplace, resignation, abandonment, redundancy and recruitment, and is managed by the PD-Pillar. The number of employees who leave the work due to unplanned resignation and who are removed from the work is in proportion to the number of employees of the employer and it is aimed to decrease this ratio with WCM applications.

Turnover Rate $=\left(\frac{\text { Redundant Labor }}{\text { Total Employees }}\right) \times 100$ 


\section{World Class Manufacturing (WCM) Model and Operational Performance Indicators: Comparison Between WCM Firms}

\section{Environment (ENV) Pillar Performance Indicators}

Effective use of resources (raw materials, water and energy), nonuse of pollutant raw materials (toxic and hazardous raw materials) and reduction of quantity and pollution rates of all wastes during the production process constitute ENV-Pillar studies. With the ENV-Pillar, it is possible to reduce the negative effects on the environment during the lifetime of the product from the raw material to its final use.

- Hazardous Waste Reduction: The ENV-Pillar works by conserving natural resources, preventing resource waste and reducing the amount of waste that needs to be disposed of. Zero waste management is defined as a waste management philosophy aiming at the re-evaluation of the wastes generated and the prevention of waste generation during the formation of wastes. With this strategy, wastes are prevented before they occur.

Hazardous Waste $=\frac{\text { Waste Amount }(\mathrm{gr})}{\text { Vehicle type }}$

Operational pillars in WCM model are independent from each other but they have mutually influencing situations. The KAIs of the WCM model operational pillars are shared with each other and the results are evaluated in a single way so that these results can be tracked and operational performance indicators are tracked in harmony. In order to coordinate this situation, operational performance must be monitored by KPIs and the pillars and applications left behind in practice are uncovered and organized.

\section{BENCHMARK OF WCM FIRMS}

The International Union, United Automobile, Aerospace and Agricultural Implement Workers of America (UAW) and Chrysler National Training Center (NTC) have joint and established World Class Manufacturing Academy in 2006 (UAW-Chrysler, 2016). Nowadays, WCM Academy is managed by FCA Group and WCM experts are trained in there and auditing system is developed by them. The WCM model is measured by this system when it comes to the application level. The audit system shows the success of the application with a score between $0-100$ and is evaluated periodically. Evaluation is carried out by the experienced supervisors of the WCM model. Each pillar is evaluated within itself and takes a value between 0 - 5 points. It is aimed to reach a total of 100 
points for the institution that implemented the WCM model with an evaluation that operational pillars are 50 points and managerial pillars are 50 points. The best practitioners are called bronze, silver, gold and world class. The WCM model is awarded bronze medal with a total of 50 points and is rated bronze in the range of $50-60$ points. The practitioner who has reached 60 points is awarded with silver medal and is in silver level between 60 - 70 points. Those who exceed 70 points are also awarded with a gold medal and are in gold level between $70-85$ points. When it reaches 85 points, it is called world class. It is ensured that their work continues to perform better than the highest score achieved with four different prize levels (FCA, 2016).

The WCM measurement model is in line with the awards that WCM applications receive in the reactive-preventive-proactive stages. The WCM measurement model requires the establishment, introduction and regular follow-up of the identification and follow-up of the device during the reactive phase of WCM applications. At this point, WCM can be termed "fast-moving" in its applications, according to its rapid progression rate during the initial period. The second stage of WCM applications, the preventative phase, shows that the activities are reaching a level that can be met by measuring the success of the practice, and the applications that deserve the bronze medal are taking the bronze medal in the WCM prize model and the silver medal level in parallel with the performance progress made in the later stages of the preventive phase. The end of the preventive stage and the beginning of the proactive stage are considered to be the gold medal level. The end of the proactive phase is seen as a world class when there is a phase following development with endless and continuous improvement (Djordjevic et al., 2010; Midor, 2012).

In this study, two enterprises that implement the WCM model are compared. The first is in preventive stage and bronze medal level. Established in 1975 by combining five strong company experiences from three European countries (Italy, France and Germany), the company is now a Bronze medalist WCM practitioner. As the pioneer player in the global transportation world, it is an international leader in the development, production and marketing of light, medium and heavy commercial vehicles. Vehicles are manufactured using the highest level technologies developed in 6 research centers in 27 production facilities located in 16 countries worldwide. The second enterprise, which is in reactive phase and is called "fast moving", is an operator that began in 1980 to produce aluminum alloy wheels for automotive manufacturers (OEM). Today, as a practitioner of the latest technology and innovations, 


\section{World Class Manufacturing (WCM) Model and Operational Performance Indicators: Comparison Between WCM Firms}

the company is one of the world's leading manufacturers of rims in the "Light Metal Rim" sector, which is rapidly advancing as a WCM practitioner by 2015 . The annual wheel production capacity of the operator in central İzmir is approximately 3 million.

For benchmarking of bronze medalist and fast moving WCM operators, 10 operational pillars and 17 KPIs are used and they are exhibited in Table 1.

Table 1: Pillars and KPIs for Benchmarking

\begin{tabular}{|c|c|c|}
\hline PILLAR & KPI & KPI Code \\
\hline \multirow{2}{*}{ S } & LTA Frequency & S1 \\
\cline { 2 - 3 } & MTC Frequency & S2 \\
\hline \multirow{2}{*}{ CD } & Transformation Cost Reduction Ratio & CD1 \\
\cline { 2 - 3 } & Benefit / Cost Ratio & FI1 \\
\cline { 2 - 3 } & Kaizen Closing Timen Participation Rate & FI2 \\
\hline \multirow{2}{*}{ AA } & OEick / Standard / Major Kaizen) & FI3 \\
\cline { 2 - 3 } & Line Efficiency (WO) & AM1 \\
\hline \multirow{2}{*}{ PM } & Mean Time Between Failures (MTBF) & WO1 \\
\cline { 2 - 3 } & Internal PPM and External PPM Ratio & PM1 \\
\hline QC & Inventory Amount & QC1 \\
\hline \multirow{2}{*}{ LOG } & Equipment Life Cycle Cost (LCC) & LOG1 \\
\hline EEM & Suggestion Rate & EEM1 \\
\hline \multirow{2}{*}{ PD } & Absenteeism Rate & PD1 \\
\cline { 2 - 3 } & Turnover Rate & PD2 \\
\cline { 2 - 3 } & Hazardous Waste & PD3 \\
\hline ENV & EN1 \\
\hline
\end{tabular}

Comparison of two different WCM operating companies is exhibited in Table 1. Fast-moving operators can not follow four KPIs: "FI1 / Kaizen Closing Time", "PM1 / Mean Time To Repair", "EEM 1 / Equipment Life Cycle Cost" and "ENV1 / Hazardous Waste". Looking at these KPIs in detail, the FI3 is associated with the finishing times of kaizen. The operator firm stated that they did not follow these deadlines before. Again, the KPI value expressed by PM1 is related to the average repair time. These durations are not recorded, and when the operator's ERP system data is analyzed, it is noticed that the failure disruptions and preparation disruptions are not separated from each other and it is decided that a new module should be added. Similarly, the cost of equipment life cycle cannot be calculated because the maintenance durations within the EEM1 are not definite. ENV1 
Emre Bilgin SARI

is not a follow-up as a KPI because the operator firm has not organized ENV pillar works.

Table 2: Benchmarking of Fast Moving and Bronze Level WCM Firms

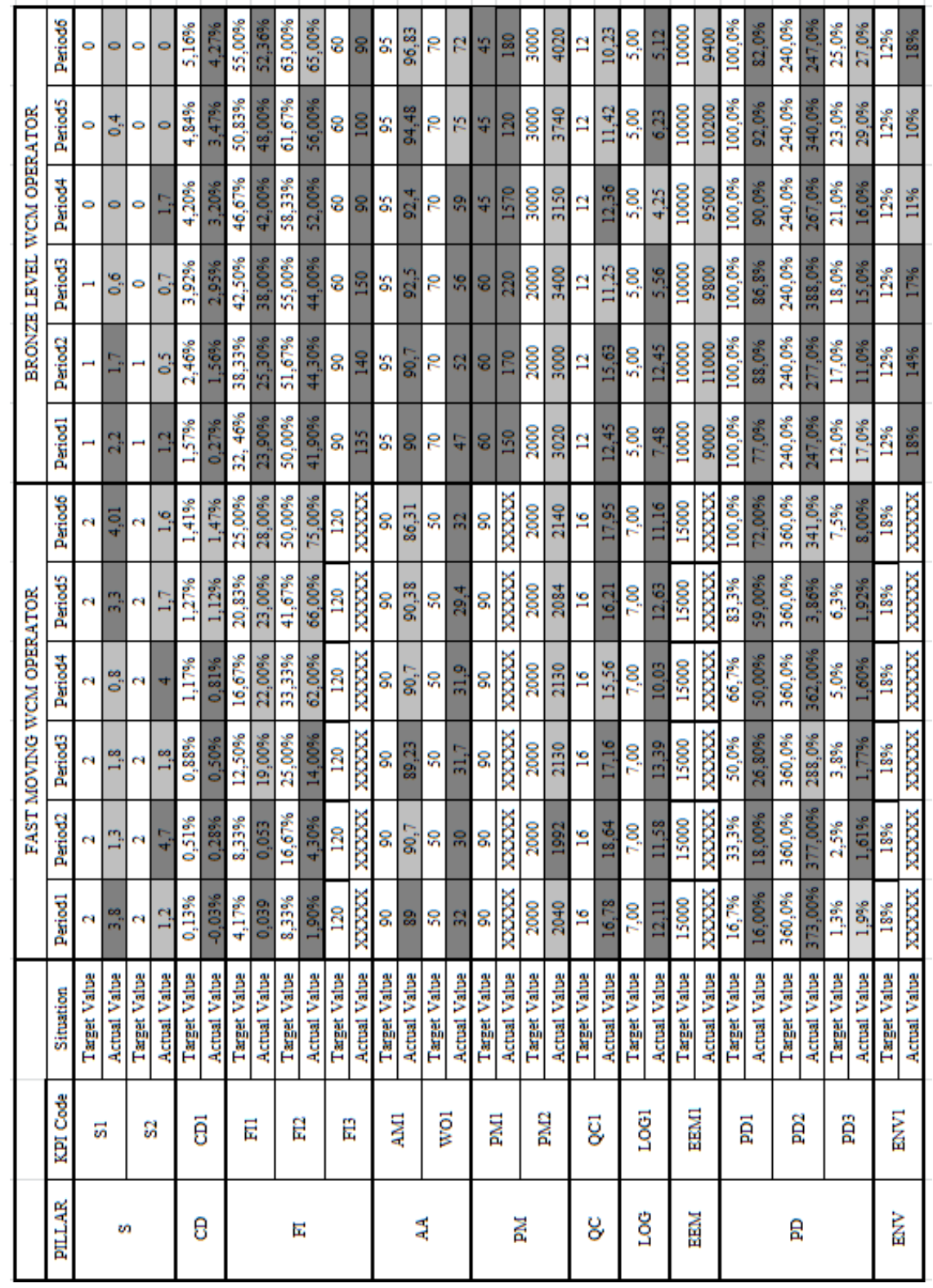




\section{World Class Manufacturing (WCM) Model and Operational Performance Indicators: Comparison Between WCM Firms}

Both operating firms follow common 13 KPIs. When commenting on these KPIs, the rate of reaching the targeted values is considered. It can be said that for the operator in the reactive phase, the rate of reaching the targets is higher. However, it is difficult to achieve because the target values are more challenging for the enterprise in the bronze level. While this is described in Table 2, the target values for each KPI are given in the upper row at reactive stage and bronze level, and these cells are left in white-colored. Actual values are listed on the bottom line of the target values for each KPI. Actual values not reaching the target value are marked with dark cells for understanding critical situations. The actual values for the target KPIs are given in light-colored cells.

Target values in WCM applications are given annually and tracked as monthly periods. The fluctuations in the values of the enterprises in the reactive stage and bronze level during the 6 months period show another difference between the enterprises. This difference is an indication that the application standard of the WCM model has not yet been fully determined. Enterprises will not be able to go to the next level unless the target value for any pillar has been reached. In addition, the KPI target will not be increased until a standard improvement is achieved for any KPI. Achieving goals in the WCM model is the main objective, but it seems that progressing in small steps demonstrates that the requirements for the follow-up KPI have been met. Difficulties in reaching these goals ensure that businesses see their deficiencies and offer permanent solutions. In this respect, the comparison of two different WCM practitioner operators draws attention to the difficulties encountered at different levels.

\section{CONCLUSION}

The WCM model is a dynamic, constantly evolving, self-renewing model. Monitoring of WCM performance is also carried out by following this change. The WCM model will have varying KPI values that must be followed by the practitioner in the course of the systemization followed by the three phases. The result from this is that the WCM model accepts the change and maintains the model for the phases it is going through again and again in order to determine the impact levels.

World Class Manufacturing is a quest for an operator to reach the bottom line, to be influenced by innovations and changes in technology, and to achieve the best continuously. This change will continue to follow the change in work to be done on the WCM model in order to monitor this 


\section{Emre Bilgin SARI}

change-over performance of enterprises implementing the WCM model. Every business has to have different and unique characteristics, to try to catch perfection in its processes and to accept itself as a philosophy of renewing.

In the light of this information, WCM model is intended to be explained as a whole. All operational pillars that make up the WCM model are considered together. The KPIs that should be followed in the success of these pillars are explained.

In the implementation phase of the study, two different companies which implement the WCM model, are compared. These two companies are WCM practitioners at different levels. It has been observed that there may be differences among the pillars that can be observed at different phases. Again, businesses that implement WCM on different levels are following the same KPIs to reach different target values. This supports the view that WCM is a dynamic, constantly evolving, self-renewing model.

This study is an original paper in terms of taking the WCM model as a whole. The study was completed by the actual data of the companies operating in the industry. However, the presence of WCM firms and the clear acquisition of their data have many difficulties. This situation is considered as a constraint in the study. However, for businesses that want to implement this practice in the industry, the follow up on the pillars may be a source for future studies in terms of explaining and formulating the proposed KPIs. These calculations can be used by sectoral practitioners as well as academic studies and can be examined by converting the working KPIs to the overall.

\section{REFERENCES}

Andersen, B., and Fagerhaug, T. (2006). Root Cause Analysis: Simplified Tools and Techniques. ABD: ASQ Quality Press.

Börjesson, A. (2011). Critical Equipment Classification and Cost Reduction Within Professional Maintenance. Master of Science Thesis in Production Engineering. Goteborg: Chalmers University of Technology.

Chaneski, W.S. (2002). "Total Productive Maintenance-An Effective Technique", Modern Machine Shop, 75 (1), 46-47.

Chiarini, A., and Vagnoni, E. (2015). World-Class Manufacturing by Fiat. Comparison with Toyota Production System from A Strategic Management, Management Accounting, Operations Management 


\section{World Class Manufacturing (WCM) Model and Operational Performance Indicators: Comparison Between WCM Firms}

and Performance Measurement Dimension. International Journal of Production Research, 53(2), 590-606.

De Felice, F., Petrillo, A., and Monfreda, S. (2013). Improving Operations Performance with World Class Manufacturing Technique: A Case in Automotive Industry. London: INTECH Open Access Publisher.

Djordjevic, M., Milovanovic, M. and Djordjevic, M. (2010). World Class Manufacturing in Automotive Industry. 4th International Quality Conference Book. Center for Quality, Faculty of Mechanical Engineering, University of Kragujevac. 185-190.

Dudek, M. (2013). Organizing of Logistic Pillar in WCM Systems. Cappathian Logistic Conference, Cracow, Poland, Congress Proceedings, $391-396$.

FCA (2016). World Class Manufacturing Audit System in Fiat Chrysler Automotive. https://www.wcm.fcagroup.com/enus/development_center/Pages/audit_system.aspx. (03.01.2019)

Ferdows, K., and De Meyer, A. (1990). Lasting Improvements in Manufacturing Performance: In Search of A New Theory. Journal of Operations Management, 9(2), 168-184.

Gajdzik, B. (2013). World Class Manufacturing In Metallurgical Enterprise. Metalurgija. 52(1), 131-134.

Midor, K. (2012). World Class Manufacturing - Characteristcs and Implementation in an Automotive Enteprise, Scientific Journals. 32 (104), 42-47.

Mishra, R. P., Anand, G., and Kodali, R. (2006). Development Of A Framework For World-Class Maintenance Systems. Journal of Advanced Manufacturing Systems, 5(2), 141-165.

Morgan, G.J. (1997). A Systems Approach to Performance Measurement Management, Technical, ACCA Student Newsletters.

Murino T., Naviglio G., Romano E., Guerra L., Revetria R., Mosca R. and Cassettari L.C. (2012). World Class Manufacturing Implementation Model. Applied Mathematics in Electrical and Computer Engineering. 371-376.

Netsis Yazlım Kullanım Dökümanları (2012). Kalite Kontrol Yenilikler http://www.netsis.com.tr/wp-

content/uploads/2012/05/Kalite_Kontrol-_80.pdf. (20.04.2016).

Pałucha, K. (2012). World Class Manufacturing Model in Production Management. Archives of Materials Science and Engineering 58(2), 227-234. 


\section{Emre Bilgin SARI}

Sarı, E. B. and Doğan, Ö. İ. (2015). Düşük Bakımın Maliyetinin Belirlenmesi ile Bakım İyileştirme Süreci Yönetimi. 15. Üretim Araştırmaları Sempozyumu Bildiriler Kitabı. 1003 - 1012.

Sarı, E.B. (2016). Dünya Klasında Üretim (WCM) Modelinde Operasyonel Performansın İzlenmesi Ve Bir Üretim İşletmesinde Uygulanması, Yayınlanmamış Doktora Tezi, Dokuz Eylül Üniversitesi, Sosyal Bilimler Enstitüsü, İzmir.

Sarı, E.B. (2018). Dünya Klasında Üretim (WCM) (World Class Manufacturing, Ankara: Detay Yayıncilık.

Schonberger, R. J. (1986). World Class Manufacturing: The Lessons of Simplicity Applied. New York: Free Press.

Shiroze, K., Total Productive Maintenance for Operators. Portland: Productivity Press.

Stanek, K., Czech, P., and Barcik, J. (2011). Metodologia World Class Manufacturing (WCM) w fabryce Fiat Auto Poland SA. Zeszyty Naukowe. Transport/Politechnika Śląska, 65-72.

Szewieczek, D., Roszak, M. T., and Helizanowicz, D. (2008). Methodology Of The Quality Management İ The Productive Process. Journal of Achievements in Materials and Manufacturing Engineering, 30(1), 87-94.

Szwejczewski, M., and Jones, M. (2012). Learning from World Class Manufacturers. UK: Palgrave Macmillan.

Temiz, İ., Atasoy, E., and Sucu, A. (2010). Toplam Ekipman Etkinliği ve Bir Uygulama.

UAW-Chrysler (2016). World Class Manufacturing Academy. http://www.uaw-chrysler.com/world-class-mfg-academy/ (18.08.2016).

Venkatraman, N., and Ramanujam, V. (1986). Measurement of Business Performance in Strategy Research: A Comparison of Approaches. Academy of Management Review, 11(4), 801-814.

Vincent, F. Y., and Hu, K. J. (2010). An Integrated Fuzzy Multi-Criteria Approach for The Performance Evaluation of Multiple Manufacturing Plants. Computers and Industrial Engineering, 58(2), 269-277.

Yamashina H. (1995). Japanese Manufacturing Strategy and The Role of Total Productive Maintenance. Journal of Quality in Maintenance Engineering. 1 (1), 27-38. 